\title{
O.V. Sukhova
}

\section{Solubility of $\mathrm{Cu}, \mathrm{Ni}$, Mn in Boron-Rich Fe-B-C Alloys}

\author{
The Oles' Honchar Dnipro National University, Dnipro, Ukraine, sukhovaya@ukr.net
}

\begin{abstract}
In the present study, the microstructure development and mechanical properties of the cast boron-rich Fe-B$\mathrm{C}$ alloys cooled at 10 and $10^{3} \mathrm{~K} / \mathrm{s}$ were investigated as functions of alloying elements additions. These alloys were prepared in the following compositional ranges: B (10 - $14 \mathrm{wt} . \%), \mathrm{C}(0.1-1.2 \mathrm{wt} . \%), \mathrm{M}(5 \mathrm{wt} . \%)$, where $\mathrm{M}-\mathrm{Cu}$, Ni or Mn, balance Fe. Structural properties were characterized by quantitative metallography, X-Ray diffraction, scanning electron microscopy, and energy dispersive spectroscopy. Mechanical properties of the structural constituents, such as microhardness and fracture toughness, were measured by a Vickers indenter. Copper becomes negligibly incorporated into the phases $\mathrm{Fe}(\mathrm{B}, \mathrm{C})$ and $\mathrm{Fe}_{2}(\mathrm{~B}, \mathrm{C})$ of the $\mathrm{Fe}-\mathrm{B}-\mathrm{C}$ alloys, but solubility limit forces the remaining solute into the residual liquid. As a result, the globular $\mathrm{Cu}$ inclusions are seen in the structure. As compared with copper, nickel has higher solubility in the constituent phases, with preferential solubility observed in the $\mathrm{Fe}_{2}(\mathrm{~B}, \mathrm{C})$ crystals, where Ni occupies Fe positions. Having limited solubility, nickel also forms secondary $\mathrm{Ni}_{4} \mathrm{~B}_{3}$ phase at the $\mathrm{Fe}_{2}(\mathrm{~B}, \mathrm{C})$ boundaries. Manganese was found to dissolve completely in the $\mathrm{Fe}-\mathrm{B}-\mathrm{C}$ alloys forming substitutional solid solutions preferentially with $\mathrm{Fe}(\mathrm{B}, \mathrm{C})$ dendrites. By entering into the iron borides structure, $\mathrm{Mn}$ and $\mathrm{Ni}$ improve their ductility but lower microhardness. The peculiarities in the structure formation and properties of the doped boron-rich $\mathrm{Fe}-\mathrm{B}-\mathrm{C}$ alloys were explained with electronic structure of the alloying elements considered.
\end{abstract}

Key words: iron borides, alloying elements, solubility, cooling rate, mechanical properties.

Received 25 January 2021; Accepted 25 February 2021.

\section{Introduction}

Boron-rich $\mathrm{Fe}-\mathrm{B}-\mathrm{C}$ alloys containing more than $10 \mathrm{wt} . \% \mathrm{~B}$ are among the few alloys to have been studied in terms of several of their physical properties, such as hardness, elevated temperature strength, and thermal stability [1-3]. Previous studies have also shown that $\mathrm{Fe}-\mathrm{B}-\mathrm{C}$ alloys have excellent wear, oxidation, and corrosion resistance [4-5]. Besides, these alloys are easily available and have the favorable cost. However, these properties can only be used for technological applications in the form of coatings [6-9] or reinforcement particles in metal matrix composites [10-11] to circumvent their intrinsic brittleness.

To apply the boron-rich $\mathrm{Fe}-\mathrm{B}-\mathrm{C}$ alloys as fillers of composites fabricated by infiltration, the contact interaction processes between the filler and the molten $\mathrm{Cu}-\mathrm{Ni}-\mathrm{Mn}$ binder should be studied [12, 13]. These processes may be accompanied by diffusion of binder constituent components, specifically $\mathrm{Cu}, \mathrm{Ni}$ or $\mathrm{Mn}$, into solid $\mathrm{Fe}-\mathrm{B}-\mathrm{C}$ filler. The performance characteristics may drastically deteriorate in case of negative influence of the diffusing elements on the structure and properties of structural constituents of the Fe-B-C alloys [14, 15].

There have been some reports regarding to the effect of $\mathrm{Cu}, \mathrm{Ni}$ or $\mathrm{Mn}$ on the microstructure and properties of the $\mathrm{Fe}-\mathrm{B}-\mathrm{C}$ alloys [16-19]. However, their examined compositions have been limited up to 3 wt. \% B [20-22]. Moreover, while the effect of the alloying elements has been studied, the effect of cooling rate on their solubility has not attracted as much attention [23-25].

So, a better understanding of the morphological modifications and properties of the $\mathrm{Fe}-\mathrm{B}-\mathrm{C}$ alloys with additional elements are necessary for practical applications. Research of the Fe-B-C alloys doped by $\mathrm{Cu}, \mathrm{Ni}$ or $\mathrm{Mn}$ and clarification of their structure is particularly important for further development of the $(\mathrm{Cu}-\mathrm{Ni}-\mathrm{Mn}$ )-matrix composites reinforced with $\mathrm{Fe}-\mathrm{B}-\mathrm{C}$ fillers. Moreover, solubility of the alloying elements may 
be influenced by changing cooling rate of the filler. Therefore, the solidification sequence and properties of the boron-rich $\mathrm{Fe}-\mathrm{B}-\mathrm{C}$ alloys were investigated as functions of additional $\mathrm{Cu}, \mathrm{Ni}$ or $\mathrm{Mn}$ amounts and cooling rate during solidification.

\section{Experimental procedure}

The composition of boron-rich $\mathrm{Fe}-\mathrm{B}-\mathrm{C}$ alloys, determined by chemical and spectral analyses, was within the concentration range of $10.0-14.0 \% \mathrm{~B}, 0.1$ $1.2 \% \mathrm{C}, 5.0 \% \mathrm{M}$ (where $\mathrm{M}-\mathrm{Cu}, \mathrm{Ni}, \mathrm{Mn}$ ), $\mathrm{Fe}-$ the remainder (in wt. \%). The specimens were prepared by melting the constituent elements of high purity (99.99\%) in a Tamman furnace and solidified at cooling rates of 10 and $10^{3} \mathrm{~K} / \mathrm{s}$.

For microstructural characterization, metallographic sections were observed by light metallographic microscope Neophot-32 and scanning electron microscope Jeol-2010 F (SEM) equipped with energydispersive spectrometer (EDS). Composition and lattice parameters of the phases in the investigated alloys as a function of composition were determined by X-ray

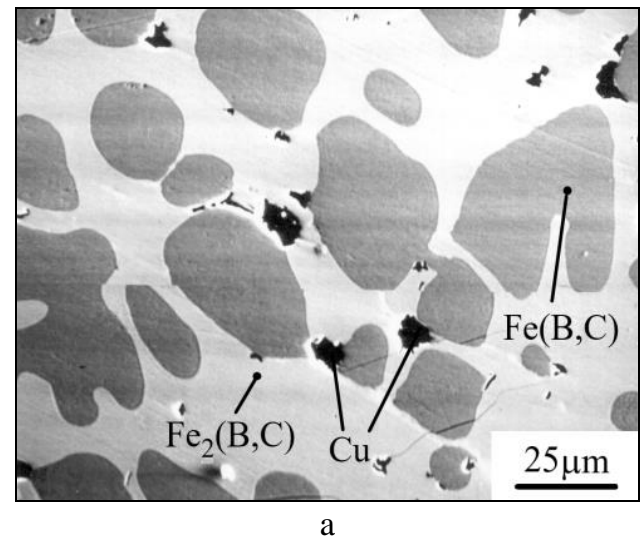

diffractometer HZG-4A with $\mathrm{CuK}_{\alpha}$ radiation.

The Vickers microhardness $\left(\mathrm{H}_{\mu}\right)$ was measured using device PMT-3 from at least 10 different indentations, and the fracture toughness $\left(\mathrm{K}_{\mathrm{IC}}\right)$ was evaluated from the crack length initiated at the corners of the Vickers microindentation using an empirical equation proposed in [26].

\section{Experimental results and discussion}

The master $\mathrm{Fe}-\mathrm{B}-\mathrm{C}$ alloys exhibit peritectic structure: primary dendrites of $\mathrm{Fe}(\mathrm{B}, \mathrm{C})$ monoboride are observed in the background of peritectically formed $\mathrm{Fe}_{2} \mathrm{~B}$ hemiboride alloyed with carbon [27]. The $\mathrm{Fe}_{2}(\mathrm{~B}, \mathrm{C})$ and $\mathrm{Fe}(\mathrm{B}, \mathrm{C})$ phases have no noticeable solubility for copper (Fig. 1) which is also confirmed by lattice parameters measurements (Table 1). As a result, globular copper inclusions appear in the structure (Fig. 1, a). Copper does not cause substantial change in the dendrite parameters of $\mathrm{Fe}(\mathrm{B}, \mathrm{C})$ crystals, as shown in Table 2, but slightly influences the microhardness and the fracture toughness of the major structural constituents (Table 3).

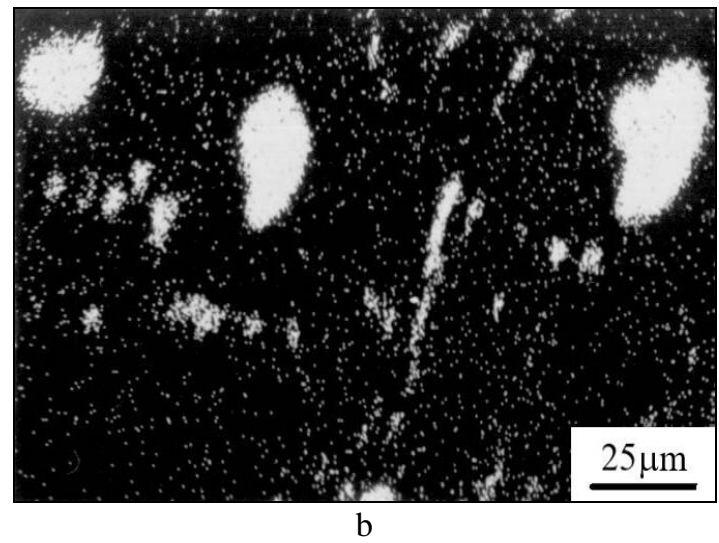

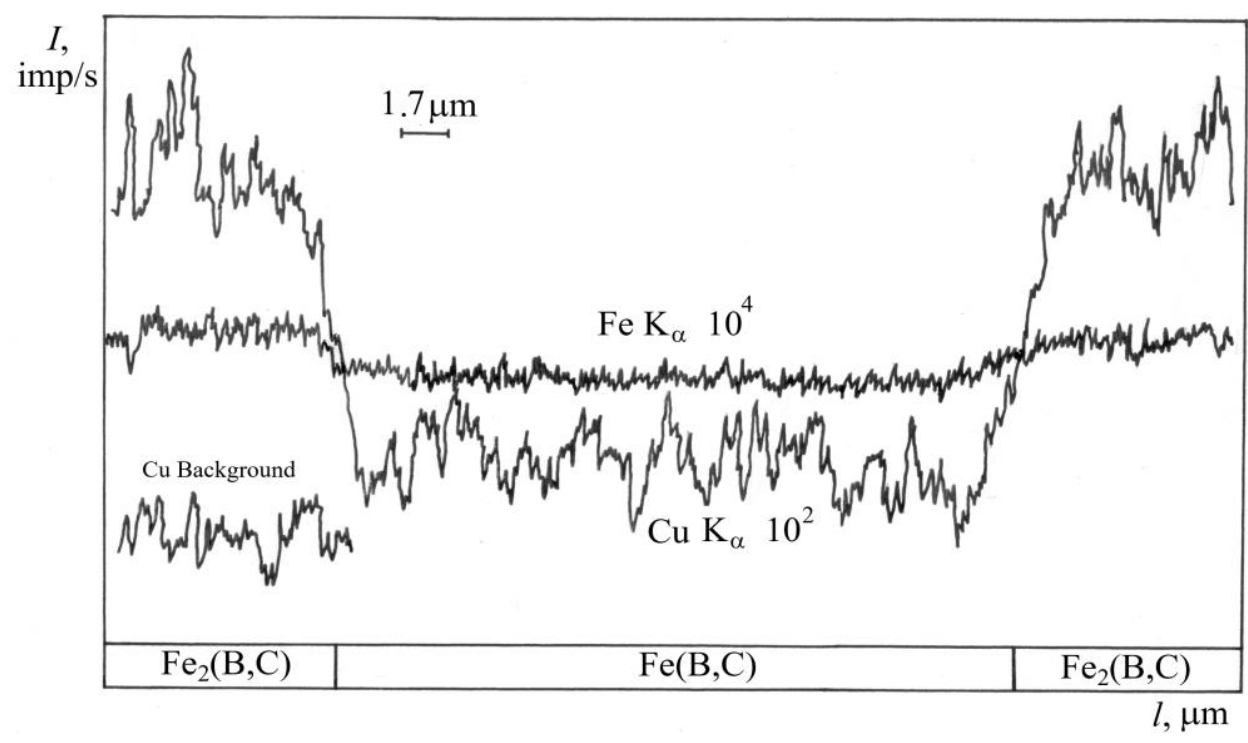

$\mathrm{c}$

Fig. 1. SEM of polished cross-sections of $\mathrm{Fe}-12.1 \% \mathrm{~B}-0.12 \% \mathrm{C}-5.0 \% \mathrm{Cu}$ alloy: $\mathrm{a}-$ second electron image; $\mathrm{b}$ - elemental EDS X-ray mapping in $\mathrm{CuK}_{\alpha}$ radiation; $\mathrm{c}$ - elemental profile along scanning line 
The lattice parameters of $\mathrm{Fe}(\mathrm{B}, \mathrm{C})$ and $\mathrm{Fe}_{2}(\mathrm{~B}, \mathrm{C})$ crystals in the doped $\mathrm{Fe}-12.1 \mathrm{~B}-0.1 \mathrm{C}-5.0 \mathrm{M}$ alloys cooled at $10 \mathrm{~K} / \mathrm{s}$

\begin{tabular}{|c|c|c|c|c|c|c|}
\hline \multirow{2}{*}{$\begin{array}{c}\text { Alloying } \\
\text { element }\end{array}$} & \multicolumn{3}{|c|}{$\mathrm{Fe}(\mathrm{B}, \mathrm{C})($ rhombic lattice) } & \multicolumn{3}{c|}{$\mathrm{Fe}_{2}(\mathrm{~B}, \mathrm{C})($ tetragonal lattice) } \\
\cline { 2 - 7 } & $\mathrm{a}, \AA$ & $\mathrm{b}, \AA$ & $\mathrm{c}, \AA$ & $\mathrm{a}, \AA$ & $\mathrm{c}, \AA$ & $\mathrm{c} / \mathrm{a}$ \\
\hline- & $5.5051 \pm 0.0061$ & $4.0628 \pm 0.0097$ & $2.9480 \pm 0.0007$ & $5.1130 \pm 0.0008$ & $4.2399 \pm 0.0035$ & 0.8292 \\
\hline $\mathrm{Cu}$ & $5.5050 \pm 0.0027$ & $4.0590 \pm 0.0036$ & $2.9472 \pm 0.0017$ & $5.1131 \pm 0.0004$ & $4.2403 \pm 0.0018$ & 0.8293 \\
\hline $\mathrm{Ni}$ & $5.5041 \pm 0.0034$ & $4.0627 \pm 0.0026$ & $2.9445 \pm 0.0025$ & $5.1116 \pm 0.0041$ & $4.2343 \pm 0.0012$ & 0.8284 \\
\hline $\mathrm{Mn}$ & $5.5350 \pm 0.0044$ & $4.0651 \pm 0.0032$ & $2.9482 \pm 0.0021$ & $5.1154 \pm 0.0024$ & $4.2405 \pm 0.0037$ & 0.8290 \\
\hline
\end{tabular}

Table 2

Influence of alloying elements on interdendritic distance $\left(l_{0}, \mu \mathrm{m}\right)$ and diameter of secondary dendritic arms $\left(d_{0}, \mu \mathrm{m}\right)$ of $\mathrm{Fe}(\mathrm{B}, \mathrm{C})$ dendrites in the doped $\mathrm{Fe}-12.1 \mathrm{~B}-0.1 \mathrm{C}-5.0 \mathrm{M}$ alloys

\begin{tabular}{|c|c|c|c|c|}
\hline \multirow{2}{*}{ Alloying element } & \multicolumn{2}{|c|}{$\mathrm{V}_{\text {cool }}=10 \mathrm{~K} / \mathrm{s}$} & $d_{0}$ & $l_{0}$ \\
\cline { 2 - 4 } & $d_{0}$ & $l_{0}$ & $4.9 \pm 0.2$ & $5.2 \pm 0.2$ \\
\hline- & $29.9 \pm 0.9$ & $33.1 \pm 0.3$ & $4.3 \pm 0.1$ & $4.6 \pm 0.1$ \\
\hline $\mathrm{Cu}$ & $28.9 \pm 0.8$ & $32.2 \pm 0.3$ & $3.8 \pm 0.1$ & $4.1 \pm 0.1$ \\
\hline $\mathrm{Ni}$ & $23.6 \pm 0.3$ & $29.0 \pm 0.1$ & $4.6 \pm 0.2$ & $4.8 \pm 0.2$ \\
\hline
\end{tabular}

Nickel slightly dissolves in $\mathrm{Fe}_{2}(\mathrm{~B}, \mathrm{C})$ crystals, and only negligible content of this element is revealed in solid solution $\mathrm{Fe}(\mathrm{B}, \mathrm{C})$ by EDS analysis (Fig. 2). This implies that, due to limited solubility, $\mathrm{Ni}$ is continually pushed out in the melt ahead of the moving solid-liquid interface into the interdendritic regions of growing $\mathrm{Fe}(\mathrm{B}, \mathrm{C})$ dendrites slowing their growth and causing noticeable refinement (Table 2). As a result, the secondary crystals of $\mathrm{Ni}_{4} \mathrm{~B}_{3}$ appear at the $\mathrm{Fe}_{2}(\mathrm{~B}, \mathrm{C})$ boundaries (Fig. 2, a).

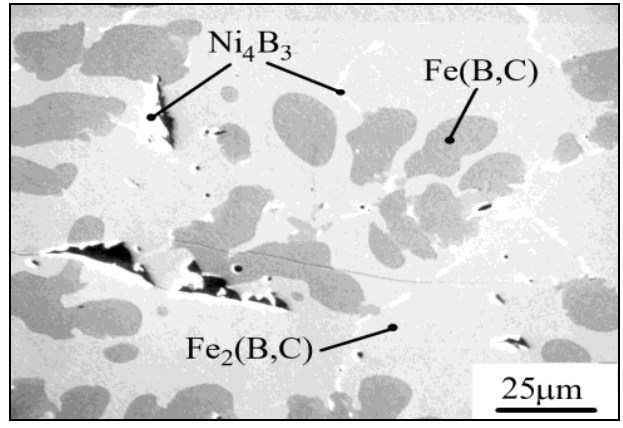

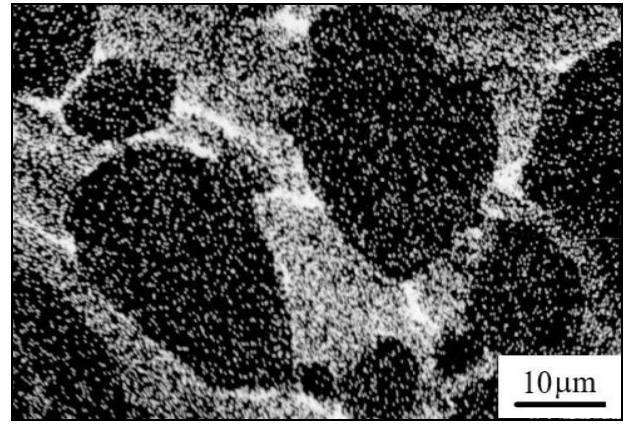

b

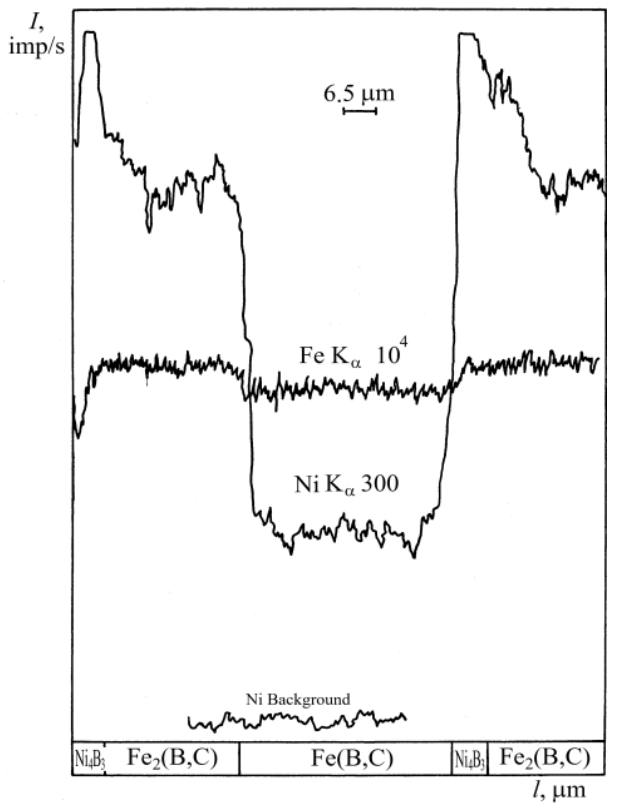

$\mathrm{C}$

Fig. 2. SEM of polished cross-sections of $\mathrm{Fe}-12.1 \% \mathrm{~B}-0.12 \% \mathrm{C}-5.0 \% \mathrm{Ni}$ alloy: $\mathrm{a}-$ second electron image; $\mathrm{b}$ - elemental EDS X-ray mapping in $\mathrm{NiK}_{\alpha}$ radiation; $\mathrm{c}$ - elemental profile along scanning line 
Table 3

Influence of alloying elements on microhardness $\left(\mathrm{H}_{\mu}, \mathrm{GPa}\right)$ and fracture toughness $\left(\mathrm{K}_{1 \mathrm{C}}, \mathrm{MPa} \cdot \sqrt{M}_{\mathrm{M}}\right)$ of $\mathrm{Fe}_{2}(\mathrm{~B}, \mathrm{C})$ and $\mathrm{Fe}(\mathrm{B}, \mathrm{C})$ solid solutions in the doped $\mathrm{Fe}-12.1 \mathrm{~B}-0.1 \mathrm{C}-5.0 \mathrm{M}$ alloys

\begin{tabular}{|c|c|c|c|c|c|c|c|c|}
\hline \multirow{2}{*}{$\begin{array}{c}\text { Alloying } \\
\text { element }\end{array}$} & \multicolumn{4}{|c|}{$\mathrm{V}_{\text {cool }}=10 \mathrm{~K} / \mathrm{s}$} & \multicolumn{4}{c|}{$\mathrm{V}_{\text {cool }}=10^{3} \mathrm{~K} / \mathrm{s}$} \\
\cline { 2 - 9 } & \multicolumn{2}{|c|}{$\mathrm{Fe}(\mathrm{B}, \mathrm{C})$} & \multicolumn{2}{c|}{$\mathrm{Fe}_{2}(\mathrm{~B}, \mathrm{C})$} & \multicolumn{2}{c|}{$\mathrm{Fe}(\mathrm{B}, \mathrm{C})$} & \multicolumn{2}{c|}{$\mathrm{Fe}_{2}(\mathrm{~B}, \mathrm{C})$} \\
\cline { 2 - 9 } & $\mathrm{H}_{\mu}$ & $\mathrm{K}_{1 \mathrm{C}}$ & $\mathrm{H}_{\mu}$ & $\mathrm{K}_{1 \mathrm{C}}$ & $\mathrm{H}_{\mu}$ & $\mathrm{K}_{1 \mathrm{C}}$ & $\mathrm{H}_{\mu}$ & $\mathrm{K}_{1 \mathrm{C}}$ \\
\hline- & $17.8 \pm 0.3$ & $2.1 \pm 0.2$ & $15.8 \pm 0.2$ & $2.2 \pm 0.3$ & $20.1 \pm 0.3$ & $5.0 \pm 0.2$ & $17.0 \pm 0.1$ & $4.0 \pm 0.1$ \\
\hline $\mathrm{Cu}$ & $17.7 \pm 0.2$ & $2.1 \pm 0.1$ & $15.6 \pm 0.3$ & $2.3 \pm 0.2$ & $20.1 \pm 0.4$ & $5.0 \pm 0.1$ & $16.8 \pm 0.2$ & $4.6 \pm 0.3$ \\
\hline $\mathrm{Ni}$ & $17.1 \pm 0.2$ & $2.4 \pm 0.1$ & $15.3 \pm 0.1$ & $2.8 \pm 0.2$ & $19.8 \pm 0.3$ & $5.2 \pm 0.2$ & $16.0 \pm 0.3$ & - \\
\hline $\mathrm{Mn}$ & $17.2 \pm 0.1$ & $3.5 \pm 0.1$ & $15.2 \pm 0.1$ & $2.6 \pm 0.2$ & $19.3 \pm 0.2$ & - & $15.9 \pm 0.2$ & - \\
\hline
\end{tabular}

Manganese completely dissolves in the $\mathrm{Fe}-\mathrm{B}-\mathrm{C}$ alloys, as illustrated in Fig. 3. This element, that has some solubility in $\mathrm{Fe}_{2}(\mathrm{~B}, \mathrm{C})$ phase, is mainly accommodated in the structure of $\mathrm{Fe}(\mathrm{B}, \mathrm{C})$ crystals. Manganese slightly decreases dendrite parameters of the doped $\mathrm{Fe}(\mathrm{B}, \mathrm{C})$ crystals (Table 2).

Manganese like nickel occupies iron positions in the crystalline lattices of the constituent phases forming substitutional solid solutions as the results of XRD measurements show (Table 1). Besides, these elements decrease microhardness $\mathrm{H}_{\mu}$ and enhance the fracture toughness $\mathrm{K}_{\mathrm{IC}}$ of the constituent phases (Table 3).

With cooling rate increasing from 10 to $10^{3} \mathrm{~K} / \mathrm{s}$, the structural composition of the boron-rich $\mathrm{Fe}-\mathrm{B}-\mathrm{C}$ alloys doped with $\mathrm{Cu}, \mathrm{Ni}$ or $\mathrm{Mn}$ yields no significant changes, only constituent phases become smaller (Table 2). Solubility behaviour of the alloying elements proves to be similar to that in the alloys cooled at $10 \mathrm{~K} / \mathrm{s}$ (Table 4). Their additions decrease microhardness $\mathrm{H}_{\mu}$ and increase fracture toughness $\mathrm{K}_{1 \mathrm{C}}$ of $\mathrm{Fe}_{2}(\mathrm{~B}, \mathrm{C})$ and $\mathrm{Fe}(\mathrm{B}, \mathrm{C})$ phases in the following sequence: $\mathrm{Cu} \rightarrow \mathrm{Ni} \rightarrow \mathrm{Mn}$ (Table 3 ).

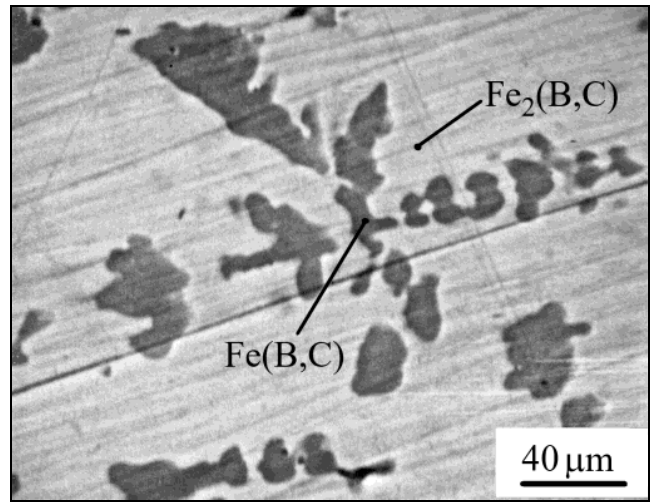

a

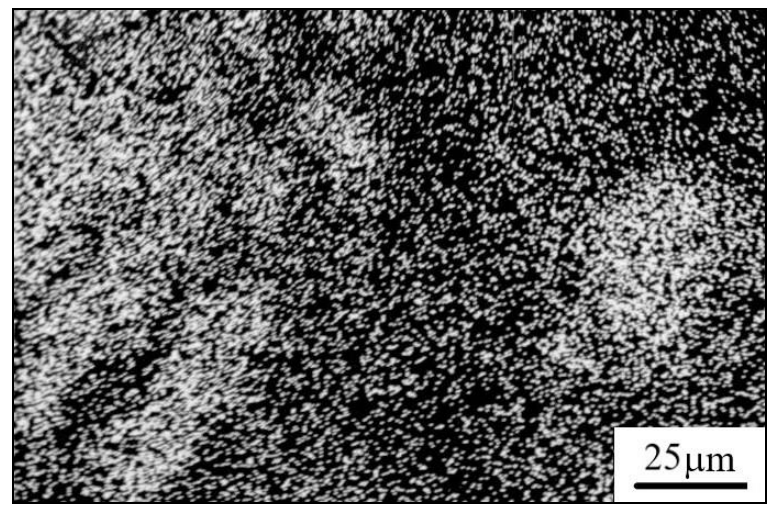

b

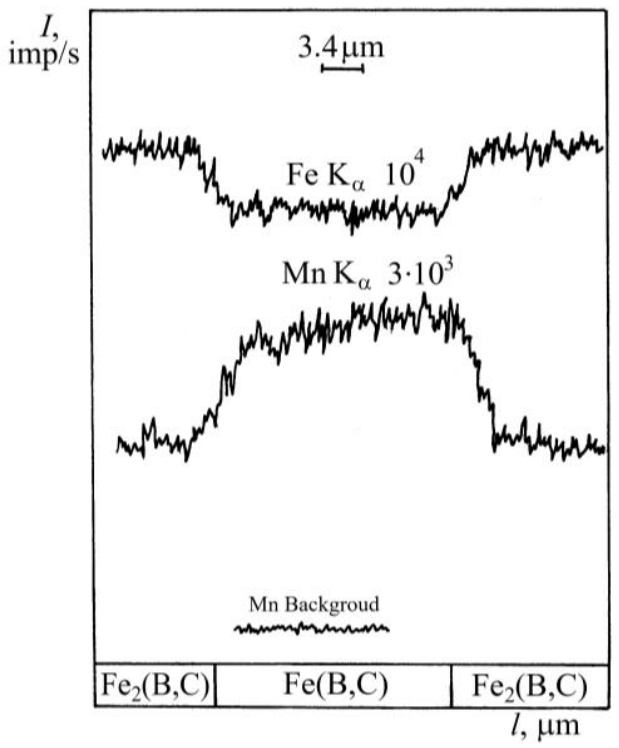

c

Fig. 3. SEM of polished cross-sections of $\mathrm{Fe}-12.1 \% \mathrm{~B}-0.12 \% \mathrm{C}-5.0 \% \mathrm{Mn}$ alloy: a - second electron image; $\mathrm{b}$ - elemental EDS X-ray mapping in $\mathrm{MnK}_{\alpha}$ radiation; $\mathrm{c}$ - elemental profile along scanning line 
The lattice parameters of $\mathrm{Fe}(\mathrm{B}, \mathrm{C})$ and $\mathrm{Fe}_{2}(\mathrm{~B}, \mathrm{C})$ crystals in the doped $\mathrm{Fe}-12.1 \mathrm{~B}-0.1 \mathrm{C}-5.0 \mathrm{M}$ alloys cooled at $10^{3} \mathrm{~K} / \mathrm{s}$

\begin{tabular}{|c|c|c|c|c|c|c|}
\hline \multirow{2}{*}{$\begin{array}{c}\text { Alloying } \\
\text { element }\end{array}$} & \multicolumn{3}{|c|}{$\mathrm{Fe}(\mathrm{B}, \mathrm{C})($ rhombic lattice $)$} & \multicolumn{3}{c|}{$\mathrm{Fe}_{2}(\mathrm{~B}, \mathrm{C})$ (tetragonal lattice) } \\
\cline { 2 - 7 } & $\mathrm{a}, \AA$ & $\mathrm{b}, \AA$ & $\mathrm{c}, \AA$ & $\mathrm{a}, \AA$ & $\mathrm{c}, \AA$ & $\mathrm{c} / \mathrm{a}$ \\
\hline- & $5.5041 \pm 0.0052$ & $4.0596 \pm 0.0106$ & $2.9501 \pm 0.0037$ & $5.1120 \pm 0.0001$ & $4.2418 \pm 0.0011$ & 0.8298 \\
\hline $\mathrm{Cu}$ & $5.5031 \pm 0.0002$ & $4.0590 \pm 0.0022$ & $2.9502 \pm 0.0018$ & $5.1123 \pm 0.0012$ & $4.2413 \pm 0.0026$ & 0.8296 \\
\hline $\mathrm{Ni}$ & $5.5009 \pm 0.0010$ & $4.0588 \pm 0.0008$ & $2.9697 \pm 0.0011$ & $5.1100 \pm 0.0004$ & $4.2367 \pm 0.0003$ & 0.8291 \\
\hline $\mathrm{Mn}$ & $5.5065 \pm 0.0027$ & $4.0640 \pm 0.0033$ & $2.9573 \pm 0.0037$ & $5.1144 \pm 0.0024$ & $4.2447 \pm 0.0035$ & 0.8299 \\
\hline
\end{tabular}

The observed peculiarities in the solubility of $\mathrm{Cu}, \mathrm{Ni}$, and $\mathrm{Mn}$ in the structural constituents of the boron-rich $\mathrm{Fe}-\mathrm{B}-\mathrm{C}$ alloys may be explained as follows. Mn noticeably dissolves in the lattice of $\mathrm{Fe}(\mathrm{B}, \mathrm{C})$ phase, but $\mathrm{Ni}$ - in the lattice of $\mathrm{Fe}_{2}(\mathrm{~B}, \mathrm{C})$ crystals. It may be assumed that, in the first place, the propensity for the solutes to form solid solutions involves the crystallographic aspect. The metallic radii of individual metal atoms increase in the following order: $\mathrm{Ni}<\mathrm{Fe} \leq \mathrm{Cu}<\mathrm{Mn}$ [28]. It makes understandable why $\mathrm{Mn}$ is predominantly dissolved in the rhombic lattice of $\mathrm{Fe}(\mathrm{B}, \mathrm{C})$ than in more close-packed tetragonal lattice of $\mathrm{Fe}_{2}(\mathrm{~B}, \mathrm{C})$ and why $\mathrm{Ni}$ behaves opposite. The $\mathrm{Mn}$ and $\mathrm{Ni}$ solute atoms incorporate into the solvent crystalline lattices substitutionally by replacing iron atoms. Compared with manganese, nickel has smaller atomic radius and, therefore, affect the lattice parameters of the phases in a lower extent.

However, considering only the crystallographic aspect does not allow to explain why manganese, which atoms are larger than the iron atoms, has complete solubility but copper which atoms have similar size negligibly dissolves in the iron borides. Therefore, in addition to crystallographic aspect, the electronic structure of alloying elements should be considered. As known, the structure and properties of $\mathrm{Fe}_{2}(\mathrm{~B}, \mathrm{C})$ phase depend on the strength and directionality of the $\mathrm{Fe}-\mathrm{B}$ and $\mathrm{Fe}-\mathrm{Fe}$ bonds, and $\mathrm{Fe}(\mathrm{B}, \mathrm{C})$ phase - on those of the $\mathrm{B}-\mathrm{B}$ and $\mathrm{Fe}-\mathrm{Fe}$ bonds [29]. The strength of these bonds is determined by the distraction of collectivized valence electrons of iron. The valence electrons of $\mathrm{Mn}$ are partially localized in the stable $\mathrm{d}^{5}$-configurations and partially are collectivized. That is why, this element acts as electron acceptor. In electronic exchange between the atoms of iron and manganese, some electrons of iron localized in $\mathrm{d}^{10}$-configurations transfer to $\mathrm{d}^{5}$-configurations of manganese with energy gain. This contributes to the complete solubility of manganese in the lattices of iron borides.

As compared with manganese, nickel and copper have much lower electron localization degree that drastically decreases up to $2 \%$ and $0 \%$ correspondingly [30]. Therefore, acceptor ability of nickel used to be worse than that of manganese. As a result, this element has limited solubility in the iron borides. Electron configuration of copper is $\mathrm{d}^{10} \mathrm{~s}^{2}$, therefore its ions cannot accept additional electrons and may be only donors of valence electrons. Any rearrangement of the bonding electrons in such system may result in the energetically non-advantageous destruction of the stable configurations. Therefore the solubility of $\mathrm{Cu}$ in $\mathrm{Fe}(\mathrm{B}, \mathrm{C})$ or $\mathrm{Fe}_{2}(\mathrm{~B}, \mathrm{C})$ crystals is negligible.

Thus, the ions of alloying elements form to boron the same interatomic bonds as iron. As a result of the substitution of $\mathrm{Fe}$ by $\mathrm{Mn}$ or $\mathrm{Ni}$ the fewer bonding electrons take part in the electronic exchange. The B-B and $\mathrm{Fe}-\mathrm{B}$ bonds become weaker and, therefore, the microhardness and the brittleness of the $\mathrm{Mn}$ - and Nicontaining solid solutions are found to decrease.

\section{Conclusions}

Substitution of $\mathrm{Fe}$ in boron-rich $\mathrm{Fe}-\mathrm{B}-\mathrm{C}$ alloys, containing $10.0-14.0 \% \mathrm{~B} ; 0.1-1.2 \% \mathrm{C} ; \mathrm{Fe}-$ the remainder, by $5.0 \mathrm{M}$ (where $\mathrm{M}-\mathrm{Cu}, \mathrm{Ni}$, or $\mathrm{Mn}$ ) (in wt. \%) does not greatly affect the solidification morphology of the $\mathrm{Fe}(\mathrm{B}, \mathrm{C})$ and $\mathrm{Fe}_{2}(\mathrm{~B}, \mathrm{C})$ solid solutions that are major structural constituents of the alloys. The solidification process consists of the primary crystallization of $\mathrm{Fe}(\mathrm{B}, \mathrm{C})$ dendrites and peritectic reaction forming the $\mathrm{Fe}_{2}(\mathrm{~B}, \mathrm{C})$ phase.

The negligible dissolution of $\mathrm{Cu}$ in the $\mathrm{Fe}-\mathrm{B}-\mathrm{C}$ alloys is responsible for the appearance of globular inclusions of copper in the structure. This result may be explained by electronic structure of copper that does not supply necessary electrons for the electronic exchange. Copper influences the mechanical properties of the $\mathrm{Fe}-\mathrm{B}-\mathrm{C}$ alloys via precipitation of secondary copper globules that may enhance, for example, antifriction properties of the alloys.

As compared with copper, solubility of nickel in the $\mathrm{Fe}-\mathrm{B}-\mathrm{C}$ alloys increases and prevails in $\mathrm{Fe}_{2}(\mathrm{~B}, \mathrm{C})$ phase. Nickel has a limited solubility and, therefore, this element is also found in the alloys in the form of $\mathrm{Ni}_{4} \mathrm{~B}_{3}$ crystals precipitated at $\mathrm{Fe}_{2}(\mathrm{~B}, \mathrm{C})$ boundaries. $\mathrm{Ni}$ introduces the smallest lattice distortions which relates to the relatively small differences in the atomic sizes between the iron and substituting atom.

When adding manganese to $\mathrm{Fe}-\mathrm{B}-\mathrm{C}$ alloys, this element has complete solubility in the structural constituents, preferentially dissolving in $\mathrm{Fe}(\mathrm{B}, \mathrm{C})$ phase. The higher solubility of manganese against nickel may be explained by the higher acceptor ability of the element.

The atoms of nickel and manganese form substitutional solutions in the crystal lattices of iron borides which weakens bonds in the solid solutions. Therefore, alloying with nickel and manganese decreases microhardness and increases fracture toughness of structural constituents. 
With cooling rate of the boron-rich $\mathrm{Fe}-\mathrm{B}-\mathrm{C}$ alloys increasing from 10 to $10^{3} \mathrm{~K} / \mathrm{s}$, solubility of $\mathrm{Cu}, \mathrm{Ni}$ and $\mathrm{Mn}$ in $\mathrm{Fe}(\mathrm{B}, \mathrm{C})$ and $\mathrm{Fe}_{2}(\mathrm{~B}, \mathrm{C})$ solid solutions remains unchanged. The size of structural constituents decreases but their microhardness and fracture toughness increases.

The obtained results clearly demonstrate the ways to control the processes of contact interaction between the $\mathrm{Fe}-\mathrm{B}-\mathrm{C}$ fillers and the $\mathrm{Cu}-\mathrm{Ni}-\mathrm{Mn}$ matrix during infiltration of macroheterogeneous composite coatings featuring high abrasive and gas-abrasive wear resistance at elevated temperatures.

Sukhova O.V. - Full Professor, Dr Sci Eng., Professor of Experimental Physics Chair.

[1] V. Homolova, L. Ciripova, A. Vyrostkova, Journal of Phase Equilibria and Diffusion 36(6), 599 (2015) (https://doi.org/10.1007/s11669-015-0424-0).

[2] Z.F. Huang, J.D. Xing, S.Q. Ma, Y.M. Gao, M. Zheng, L.Q. Sun, Key Engineering Materials 732, 59 (2017) (https://doi.org/10.4028/www.scientific.net/kem.732.59).

[3] A. Sudo, T. Nishi, N. Shirasu, M. Takano, M. Kurata, Journal of Nuclear Science and Technology 52(10), 1308 (2015) (https://doi.org/10.1080/00223131.2015.1016465).

[4] X. Ren, H. Fu, J. Xing, Y. Yang, S. Tang, Journal of Materials Research 32(16), 304 (2017) (https://doi.org/10.1557/jmr.2017.304).

[5] P. Sang, H. Fu, Y. Qu, C. Wang, Y. Lei, Materialwissenschaft Und Werkstofftechnik 46(9), 962 (2015) (https://doi.org/10.1002/mawe.201500397).

[6] I.M. Spyrydonova, O.V. Sukhova, G.V. Zinkovskij, Metallurgical and Mining Industry 4(4), 2 (2012).

[7] S.I. Ryabtsev, V.A. Polonskyy, O.V. Sukhova, Powder Metallurgy and Metal Ceramics 58(9-10), 567 (2020) (https://doi.org/10.1007/s11106-020-00111-2).

[8] O.V. Sukhova, V.A. Polonskyy, K.V. Ustinova, Materials $\quad$ Science $55(2), \quad 285 \quad$ (2019) (https://doi.org/10.1007/s11003-019-00302-2).

[9] O.V. Sukhova, Y.V. Syrovatko, Metallofizika i Noveishie Tekhnologii 41(9), 1171 (2019) (https://doi.org/10.15407/mfint.41.09.1171).

[10] Z. M. Rykavets, J. Bouquerel, J.-B. Vogt, Z. A. Duriagina, V. V. Kulyk, T. L. Tepla, L. I. Bohun, T. M. Kovbasyuk, Progress in Physics of Metals 20(4), 620 (2019) (https://doi.org/10.15407/ufm.20.04.620).

[11] O.P. Ostash, V.V. Kulyk, T.M. Lenkovskiy, Z.A. Duriagina, V.V. Vira, T.L. Tepla, Archives of Materials Science and Engineering 90(2), 49 (2018) (https://doi.org/10.5604/01.3001.0012.0662).

[12] I.M. Spiridonova, E.V. Sukhovaya, S.B. Pilyaeva, O.G. Bezrukavaya, Metallurgical and Mining Industry 3 , 58 (2002).

[13] Z.A. Duriagina, M.R. Romanyshyn, V.V. Kulyk, T.M. Kovbasiuk, A.M. Trostianchyn, I.A. Lemishka, Journal of Achievements in Materials and Manufacturing Engineering 100(2), 49 (2020) (https://doi.org/10.5604/01.3001.0014.3344).

[14] I.M. Spiridonova, O.V. Sukhova, A.P. Vashchenko, Metallofizika i Noveishie Tekhnologii 21(2), 122 (1999).

[15] O.P. Ostash, V.H. Anofriev, I.M. Andreiko, L.A. Muradyan, V.V. Kulyk, Materials Science 48(6), 697 (2013) (https://doi.org/10.1007/s11003-013-9557-7).

[16] Yu.G. Chabak, V.I. Fedun, T.V. Pastukhova, V.I. Zurnadzhy, S.P. Berezhnyy, V.G. Efremenko, Problems of Atomic Science and Technology 110(4), 97 (2017).

[17] S. Egashira, T. Sekiya, T. Ueno, $\quad$ M. Fujii, $\quad$ Mechanical $\quad$ Engineering Journal 6(6), 19 (2019) (https://doi.org/10.1299/mej.19-00297).

[18] M.I. Pashechko, K. Dziedzic, M. Barszcz, Advances in Science and Technology Research Journal 10(31), 194 (2016) (https://doi.org/10.12913/22998624/64020).

[19] K. Lee, M. Choi, G. Lee, M. Kim, J. Kim, IEEE Transactions on Magnetics 1-4, (2018) (https://doi.org/10.1109/tmag.2018.2878292).

[20] L. Sidney, Alloy Steel: Property and Use (Scitus Academics LLC, Wilmington, 2016).

[21] O.V. Sukhova, K.V. Ustinova, Functional Materials 26(3), 495 (2019) (https://doi.org/10.15407/fm26.03.495).

[22] J. Miettinen, V.-V. Visuri, T. Fabritius, Archives of Metallurgy and Materials 66(1), 297 (2021) (https://doi.org/10.24425/amm.2021.134787).

[23] W. Shenglin, China Welding 27 (4), 46 (2018) (https://doi.org/10.12073/j.cw.20180603001).

[24] M. Zhang, X. Wang, S. Liu, K. Qu, Journal of Rare Earths 13(5), (2019) (https://doi.org/10.1016/j.jre.2019.05.013).

[25] Z. Chen, S. Miao, L. Kong, X. Wei, F. Zhang, H. Yu, Materials 13(4), 975 (2020) (https://doi.org/0.3390/ma13040975).

[26] K. Niihara, R. Morena, P.H. Hasselman, Journal of Materials $\quad$ Science Letters $1, \quad 13 \quad$ (1982) (https://doi.org/10.1007/BF00724706).

[27] O.V. Sukhova, Physics and Chemistry of Solid State 21(2), 355 (2020) (https://doi.org/10.15330/pcss.21.2.355$\underline{360})$.

[28] C.J. Smithells, Metals Reference Book (Butterworth and Co., London \& Boston, 1976).

[29] G. Li, D. Wang, Journal of Physics of Condensed Matter 1, 1799 (1989).

[30] G.V. Samsonov, I.F. Pryadko, L.F. Pryadko, Electron Localization in Solids (Nauka, Moscow, 1976). 
О.В. Сухова

\title{
Розчинність Cu, Ni, Mn у високобористих сплавах Fe-B-C
}

\author{
Дніпровський національний університет імені Олеся Гончара, Дніпро, Украӥна, sukhovaуa@ukr.net
}

В роботі досліджували вплив легуючих елементів на процеси формування структури та механічні властивості литих високобористих сплавів $\mathrm{Fe}-\mathrm{B}-\mathrm{C}$, охолоджених зі швидкостями $10 \mathrm{i} 10^{3} \mathrm{~K} / \mathrm{c}$. Склад сплавів знаходився в наступному концентраційному діапазоні: В (10 - 14 ваг.\%), С (0,1 - 1,2 ваг.\%), М (5 ваг.\%), де $\mathrm{M}$ - $\mathrm{Cu}$, Ni чи $\mathrm{Mn}, \mathrm{Fe}$ - залишок. Структуру сплавів вивчали методами кількісної металографії, рентгеноструктурного аналізу, сканувальної електронної мікроскопії, рентгеноспектрального мікроаналізу. Механічні властивості структурних складових, а саме мікротвердість і коефіцієнт тріщиностійкості, вимірювали на мікротвердомірі Віккерса. Мідь має нехтовно малу розчинність у фазах $\mathrm{Fe}(\mathrm{B}, \mathrm{C})$ та $\mathrm{Fe}_{2}(\mathrm{~B}, \mathrm{C})$ високобористих сплавів $\mathrm{Fe}-\mathrm{B}-\mathrm{C}$, тому цей елемент залишається в рідині під час кристалізації. В результаті по iii закінченні в структурі спостерігаються глобулярні включення $\mathrm{Cu}$. Порівняно з міддю нікель розчиняється в структурних складових сплавів у більшій кількості, переважно заміщуючи $\mathrm{Fe}$ в решітці фази $\mathrm{Fe}_{2}(\mathrm{~B}, \mathrm{C})$. Маючи обмежену розчинність, нікель також утворює вторинну фазу $\mathrm{Ni}_{4} \mathrm{~B}_{3}$ по границях кристалів $\mathrm{Fe}_{2}(\mathrm{~B}, \mathrm{C})$. Марганець повністю розчиняється в структурних складових сплавів $\mathrm{Fe}-\mathrm{B}-\mathrm{C}$, заміщуючи залізо переважно в кристалічній гратці фази $\mathrm{Fe}(\mathrm{B}, \mathrm{C})$. Потрапляючи в структуру боридів заліза, Mn i Ni підвищують їх пластичність, але знижують мікротвердість. Особливості структуроутворення та властивості легованих високобористих сплавів $\mathrm{Fe}-\mathrm{B}-\mathrm{C}$ пояснено з урахуванням електронної структури легуючих елементів.

Ключові слова: бориди заліза, легуючі елементи, розчинність, швидкість охолодження, механічні властивості. 